International Journal of Current Microbiology and Applied Sciences

ISSN: 2319-7706 Volume 6 Number 2 (2017) pp. 1043-1052

Journal homepage: http://www.ijcmas.com

Original Research Article

http://dx.doi.org/10.20546/ijcmas.2017.602.117

\title{
Effect of Capsicum on the Physico-Chemical Properties and Sensory Attributes of Chicken Sausages
}

\author{
Parveez Ahmad Para ${ }^{1}$, Praveen Kumar Praveen ${ }^{2}$ and Subha Ganguly ${ }^{3}$ \\ ${ }^{1}$ Department of Livestock Products Technology, Arawali Veterinary College, \\ N.H. -52 Jaipur Road, V.P.O. Bajor, Sikar - 332001, Rajasthan, India \\ ${ }^{2}$ Department of Veterinary Public Health and Epidemiology, Arawali Veterinary College, \\ N.H. -52 Jaipur Road, V.P.O. Bajor, Sikar - 332001, Rajasthan, India \\ ${ }^{3}$ Department of Veterinary Microbiology, Arawali Veterinary College, N.H.-52 \\ Jaipur Road, V.P.O. Bajor, Sikar - 332001, Rajasthan, India \\ *Corresponding author
}

\section{A B S T R A C T}

The objective of this study was to develop chicken meat sausages with the inclusion of capsicum and to assess the $\mathrm{pH}$, cooking yield, emulsion stability, proximate composition and sensory properties. Chicken meat sausages were prepared with the addition of $0 \%, 7 \%$,

\begin{tabular}{|l|}
\hline Key w or d s \\
Chicken sausages, \\
$\begin{array}{l}\text { Capsicum, } \\
\text { Proximate } \\
\text { composition, } \\
\text { Sensory attribute. }\end{array}$ \\
\hline Article Info \\
\hline $\begin{array}{l}\text { Accepted: } \\
\text { 20 January 2017 } \\
\text { Available Online: } \\
\text { 10 February 2017 }\end{array}$ \\
\hline \hline
\end{tabular}
$14 \%$ and $21 \%$ of capsicum replacing the corresponding amount of lean meat in preparation of chicken sausages. Amongst the different physico-chemical and compositional parameters, a decrease $(\mathrm{p}<0.05)$ in $\mathrm{pH}$, emulsion stability, ash content, cooking yield as well as fat and protein percentage with each subsequent incorporation level of capsicum was accompanied by a gradual increase in moisture of the sausages. However, crude fiber content significantly $(\mathrm{p}<0.05)$ increased with increasing level of inclusion. The appearance and colour of sausages decreased gradually with the increasing level of capsicum incorporation. Appearance decreased as the level of capsicum incorporation increased, however the decrease was highest at $21 \%$ level although comparable with other levels of incorporation. The flavour, and overall acceptability scores were significantly $(\mathrm{p}<0.05)$ lower at 21 percent level as compared to control however the scores were highest at 7 percent level of incorporation which is comparable to control. Juiciness scores were significantly $(\mathrm{p}<0.05)$ higher at $21 \%$ level as compared to control and other two levels of capsicum incorporation, although the scores were comparable at 7 and $14 \%$ level of incorporation. The texture score followed a linear decreasing trend in the present study. The products with $21 \%$ added capsicum in the formulation had significantly $(\mathrm{p}<0.05)$ lower texture score as compared to control. The overall acceptability score of the products was highest at $7 \%$ level of capsicum incorporation.

\section{Introduction}

Sausages are one of the popular conveniences ready to eat meat products available worldwide. Typically, the sausage is formed in a casing traditionally made from intestine of the farm animals, but sometimes synthetic, producing the characteristic cylindrical shape utilizing ground meat and often salt, herbs and spices. The word sausage is derived from the Latin word salsus, meaning salted. Sausage making is a traditional food 
preservation technique by using curing, drying, or smoking techniques. Some sausages are cooked during processing and the casing may be removed afterwards. Sausages are one of the oldest foods known to the mankind prepared by using tissues and organs such as scraps, organ meats, and blood and fat, which are edible and nutritious but are not particularly appealing, in a form that allows for preservation. Early humans made the first sausage by stuffing roasted intestines into stomach. As early as $589 \mathrm{BC}$, a Chinese sausage (lachang) was mentioned consisting of goat and lamb meat. Evidence suggests that sausages were already popular both among the ancient Greeks and Romans and most likely among the illiterate tribes occupying the larger part of Europe. Basically people living in particular areas developed their own types of sausage and that sausage became associated with the area. For example Bologna originated in the town of Bologna in Northern Italy, Lyons sausages from Lyons in France and Berliner sausages from Berlin in Germany.

Poultry farming in India has transformed from a mere tool of supplementary income and nutritious food for the family to the major commercial activity generating the required revenue. Changing food habits, rising income of the middle class Indian, involvement of private players, rising market demand of the Indian poultry produce in the export market are some of the contributing factors to the growth of the industry. The demand of poultry meat can also be increased by developing some novel functional poultry meat products and introducing them to consumers at reasonable prices. The changes in consumer's life style and rapid expansion of the fast food market, consumers shift from a preference for live birds to processed (chilled or frozen) products and vertical integration in the poultry industry has increased the development of meat products and has come up with the introduction of several new functional meat products in recent days. These products are generally produced by reformulation of meat by incorporating ingredients like green vegetable fibres, protein, polyunsaturated fatty acids, antioxidants, vitamins and minerals etc. The food value and health benefits of different mentioned vegetables will add to the nutritional value of chicken which is deficient in fibre and vitamin $\mathrm{C}$. The changes in consumer's life style and rapid expansion of the fast food market, consumers shift from a preference for live birds to processed (chilled or frozen) products and vertical integration in the poultry industry (McDonald, 2009) has increased the development of meat products and has come up with the introduction of several new functional meat products in recent days. These products are generally produced by reformulation of meat by incorporating ingredients like green vegetable fibres, fruits, protein, polyunsaturated fatty acids, antioxidants, vitamins and minerals etc. Incorporation of fruits endorses the healthy image of meat products. In contrast to the study dealing with the health influences of the addition of vegetables, there is a very limited research about the technological, physicochemical, organoleptic, and microbiological properties of vegetable-added meats.

Capsicum is rich in carotenoids vitamin A \& $\mathrm{C}$ and provitamins. It has good antioxidant property. It promotes cardiovascular health, speeds up metabolism and burn more calories due to presence of capsaicin which stimulates hepatic and skeletal muscle fatty acid oxidation and also inhibits growth of fat cells. It has antiinflammatory action also. It stimulates stomach secretions and improves digestion (Anonymous, 2011). FernándezLópez (2002) studied the effect of paprika (Capsicum annum) on color of Spanish-type sausages during the resting stage. He noticed 
that the addition of paprika to minced meat reduced lightness. Redness values of minced meat batters with added paprika $(30 \mathrm{~g} / \mathrm{kg})$ were a result of the paprika they contain, and because the effect of the meat colour itself was masked.

The present study was envisaged to develop fiber enriched chicken meat sausages with different levels of capsicum (7\%, 14\% and $21 \%$ ) incorporation using hot air oven cooking method and to study various physiochemical and sensory parameters. These types of products provide adequate nutrition and cater well to the need of health conscious consumers.

\section{Materials and Methods}

The work was undertaken at the Department of Livestock Products Technology of Arawali Veterinary College.

Meat: Deboned chicken meat was procured from local market, packed in polythene bags, and stored at $-18^{\circ} \mathrm{C}$ till product formulation.

Spices and condiments: The extraneous matter of the spices were removed, dried overnight in an oven at $60^{\circ} \mathrm{C}$, and then pulverized with a grinder. The coarse particles were removed using a sieve, and the remnant fine particles at the required proportions was mixed to prepare the spice mixture, and was stored in plastic airtight containers for subsequent use (Formulation given in table 1). Onion, garlic and ginger $(3: 2: 1)$ were peeled, cut in small pieces and homogenized to obtain a fine paste of condiment.

Salt: Commercial brand of salt $(\mathrm{NaCl})$ viz., Tata salt from TATA chemicals limited, Mumbai procured from local market was used throughout the study.

Nitrite: Food grade nitrite supplied by $\mathrm{Hi}$ Media Laboratories Pvt. Ltd., Mumbai was used.

\section{Flow diagram for preparation of chicken sausages}

Dressed chicken

Removal of skin and fat

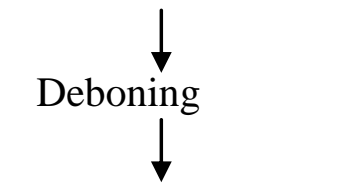

Cutting of deboned meat into smaller chunks

Mincing through $6 \mathrm{~mm}$ plate

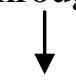

Addition of salt (1.75\%), STPP (0.3\%) and sodium nitrite $(120 \mathrm{ppm})$

Chopping for $1.5 \mathrm{~min}$

Addition of water (9\%) in the form of crushed ice

Chopping for $1 \mathrm{~min}$

Addition of vegetable oil (9\%)

Chopping for 1-2 min

Addition of spice mixture, condiments mixture and refined wheat flour

Chopping for 1.5-2 min

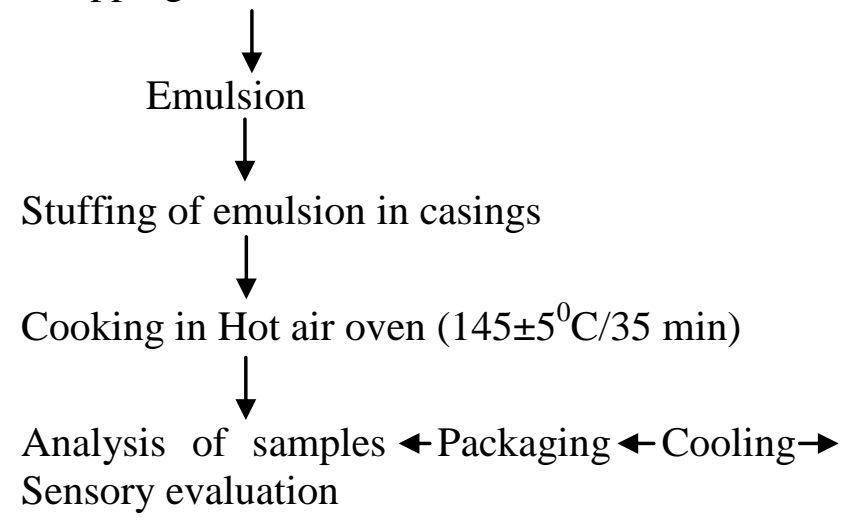


Flour: Refined wheat flour was brought from local market of Sikar

Cooking oil: Refined cotton seed oil (Mahakosh) was purchased from the local market and was used (Formulation given in table 2).

Vegetable (capsicum): Capsicum was obtained from local market of sikar. Approximately $400 \mathrm{gm}$ of capsicum was taken and washed with clean water. It was deseeded and cut into smaller pieces which were then grounded in a mixer. Excess of juice from capsicum after grinding was drained using muslin cloth to obtain capsicum paste and incorporated at $7 \%, 14 \%$ and $21 \%$ level in the formulation replacing lean meat.

Formulation of chicken sausages: Represented in table 3.

Stuffing of sausages: The emulsion was filled in to the sausage filler, and the artificial cellulose casing was applied on the nozzle of sausage filler. Pressure was applied in such a way so that the emulsion was filled in to the casings.

Cooking of sausages: Depending upon the experimental requirement, hot air oven method was used for cooking of sausages.

Hot-air oven method: Raw sausages were hanged vertically on skewers which were placed at the two ends of hot air oven. Raw sausages were cooked in a preheated hot air oven at $145 \pm 5^{0} \mathrm{C}$ for a total time of about 35 min. The internal temperature of sausages was monitored by a thermometer and cooked to an internal temperature of $90 \pm 2{ }^{\circ} \mathrm{C}$. The sausages were removed from the skewers, cooled to room temperature and weighed. Pooled sample of each treatment was assigned for analysis.
Proximate composition: The proximate composition of products, viz., moisture (\%), crude protein $(\%)$ ether extract $(\%)$, and ash $(\%)$ were determined as per the procedures of AOAC (1995).

pH: The $\mathrm{pH}$ products was measured by the method of Keller et al. (1974) with slight modification. For this purpose, $10 \mathrm{~g}$ of the sample was homogenized with $50 \mathrm{ml}$ distilled water by using pestle and mortar for $1 \mathrm{~min}$. The $\mathrm{pH}$ of the suspension was recorded by immersing combined glass electrode of digital $\mathrm{pH}$ meter.

Cooking yield: The cooking yield (\%) of chicken sausages was estimated with the following formula:

Cooking yield $(\%)=$ Weight of cooked sausages/Weight of raw sausages $\times 100$

Emulsion stability: The emulsion stability of meat emulsion was estimated as per procedure described by Townsend et al. (1968). About $25 \mathrm{~g}$ of samples were placed in polyethylene bags (Size 12 x $10 \mathrm{~cm}$ ). Bags with samples were weighed and sealed. These bags were immersed in a thermostatically controlled water bath at $80^{\circ} \mathrm{C}$ for $20 \mathrm{~min}$, the bags removed from the water bath, were cut open and cooked fluids (fat, water and solids) drained. The cooked samples were weighed. Loss of weight after cooking was calculated and expressed (in percentage) as an index of emulsion stability.

Sensory evaluation: The sensory attributes, viz., colour and appearance, flavour, texture, juiciness, and overall acceptability of the finished product was estimated by semi trained panelists, using 8-point descriptive scale, where, $1=$ extremely disliked, and $8=$ extremely liked (Semen et al., 1987). 
Experimental details: Development of chicken meat sausages by incorporating different levels of capiscum. The products containing three different levels of capsicum (7\%, $14 \%$ and $21 \%)$ were analyzed for some quality and sensory parameters using standard methods:

$\mathrm{pH}$, Cooking yield, Emulsion stability

Sensory evaluation of finished product was conducted by semi trained panelists using 8point descriptive scale, (where $1=$ extremely disliked and 8 = extremely liked), for colour and appearance, flavour, texture, juiciness and overall acceptability.

Statistical analysis: The results were analyzed statistically for analysis of variance and least significant difference tests using the software of Statistical Package for Social Sciences (SPSS 16.0) and Snedecor and Cochran (1980). The statistically analyzed results were tabulated and interpreted.

\section{Results and Discussion}

Physico-chemical qualities: There was a gradual but no significant $(p>0.05)$ decrease in $\mathrm{pH}$ with increase in the level of capsicum incorporation. This gradual reduction in $\mathrm{pH}$ might be due to low $\mathrm{pH}$ of capsicum. A significant $(\mathrm{p}<0.05)$ decreasing trend in cooking yield was observed in the products with the increasing level of incorporation of capsicum. Decrease in the emulsion stability with increase in the levels of capsicum may also act as a contributing factor for decreasing the cooking yield. This result is broadly in agreement with the observations of Verma (2009) who observed similar findings in designer chicken nuggets incorporated with high dietary fibre. Grigelmo-Miguel et al., (1999) reported addition of fibre in meat lowered the $\mathrm{pH}$ of the solution thereby of product $\mathrm{pH}$. However, they again reported that dietary fibre was effective in retaining added water in low fat frankfurters since their cooking losses were similar to those of the controls (5.5\%). The emulsion stability showed a significantly $(\mathrm{p}<0.05)$ decreasing trend with the increase in level from 0 percent to 21 percent. At $21 \%$ level it was significantly $(\mathrm{p}<0.05)$ lower as compared to control. This might be due to linear decrease in $\mathrm{pH}$ as well as interaction of water molecules of capsicum with meat proteins thereby reducing the emulsion stability (Table 4). This study is in agreement with Bhosale et al. (2011) who reported similar findings in chicken nuggets incorporated with ground carrot and mashed sweet potato at different levels $(0,5,10,15 \%)$. This could be also attributed to the higher moisture content in the capsicum pulp. A similar observation was reported by Verma et al., (2010) when they studied the effect of sodium chloride replacement and apple pulp inclusion on the physico-chemical, textural and sensory properties of low fat chicken nuggets.

A gradual increase in moisture percent was recorded and was significantly $(\mathrm{p}<0.05)$ higher at 21 percent level as compared to control and sausages prepared with incorporation of capsicum at other levels. Higher moisture percent with increasing levels of incorporation might be due to high moisture content in capsicum. GrigelmoMiguel et al., (1999) reported higher water content in meat products incorporated with fruit fibre. Bhosale et al., (2011) reported that addition of either raw carrot or mashed sweet potato represents an improvement in the nutritional value and have some beneficial effects due to the presence of dietary fibres and $\beta$-carotene. Similar result was found in low fat, high dietary fibre beef patties extended with date fibre (Hashim and Khalil, 1999). Protein content of sausages decreased significantly $\quad(\mathrm{p}<0.05) \quad$ with capsicum incorporation. Similar results were reported 
by Candogan (2002) for beef patties with added tomato paste, and by Anderson and Berry (2001) for inner pea fibre added to high-fat ground beef. A gradual decrease in ether extract was recorded and was significantly lower $(\mathrm{p}<0.05)$ at 21 percent level as compared to control. A lower fat percent among treatment products in the present study might be due to replacement of lean meat by capsicum pulp which was having lesser fat content. Similar results were reported by Valeria et al., (2008) for dry fermented sausages prepared by the incorporation of carrot dietary fibres and Aleson-Carbonell et al., (2004) for nonfermented dry-cured sausages formulated with lemon albedo. Similarly, FernandesGines et al., (2004) reported cooked lemon albedo fibres $(2.5-5 \%)$ in bolognas showed higher moisture content than control. Similar result was also found in low fat, high dietary fibre frankfurter prepared with peach dietary fibre (Grigelmo-Miguel et al., 1999). Ash percentage differed significantly $(\mathrm{p}<0.05)$ and it was least for the chicken sausages prepared with the incorporation of capsicum at $21 \%$ level. Treated samples showed lower $(\mathrm{p}<0.05)$ protein, fat and ash contents but higher $(p<0.05)$ moisture and crude fibre content than control. Kassem and Emara (2010) reported an increase in moisture, and decrease in fat, protein and ash in cooked control and vegetable (pea and carrot) treated beef burger patties. An increasing trend in crude fibre level was observed with increasing levels of incorporation. This crude fibre content was significantly $(\mathrm{p}<0.05)$ higher in the products with $21 \%$ added capsicum in the formulation. This might be due to the higher level of the incorporation of capsicum pulp. This was found in agreement with Verma et al., (2009) who observed that there was significant $(\mathrm{p}<0.05)$ increase in dietary fibre content in chicken nuggets by sodium chloride replacement and apple pulp inclusion.

Table.1 Composition of spice mixture (on weight basis)

\begin{tabular}{|l|c|}
\hline \multicolumn{1}{|c|}{ Ingredients } & Percent \\
\hline Aniseed & $14 \%$ \\
\hline Bay leaves & $02 \%$ \\
\hline Black pepper & $04 \%$ \\
\hline Green cardamom & $05 \%$ \\
\hline Cinnamon & $06 \%$ \\
\hline Cloves & $02 \%$ \\
\hline Dry fenugreek powder & $06 \%$ \\
\hline Coriander & $20 \%$ \\
\hline Cumin seed & $12 \%$ \\
\hline Mace & $02 \%$ \\
\hline Nutmeg & $02 \%$ \\
\hline Red chilli & $12 \%$ \\
\hline Black cardamom & $05 \%$ \\
\hline Mint leaves & $03 \%$ \\
\hline Dry ginger powder & $05 \%$ \\
\hline
\end{tabular}


Table.2 Composition of refined cottonseed oil 'mahakosh'per $100 \mathrm{~g}$ )

\begin{tabular}{|l|c|}
\hline Energy & $900 \mathrm{k} . \mathrm{cal}$ \\
\hline Carbohydrate & $0 \mathrm{~g}$ \\
\hline Proteins & $0 \mathrm{~g}$ \\
\hline Cholesterol & $0 \mathrm{~g}$ \\
\hline Saturated Fatty acids & $16 \mathrm{~g}$ \\
\hline Mono-unsaturated Fatty acids & $23.5 \mathrm{~g}$ \\
\hline Poly -unsaturated Fatty acids (Avg) & $54 \mathrm{~g}$ \\
\hline
\end{tabular}

Table.3 Formulation of sausages from chicken meat

\begin{tabular}{|l|c|}
\hline \multicolumn{1}{|c|}{ Ingredients } & Percentage \\
\hline Lean meat & 67.40 \\
\hline Added water & 9.0 \\
\hline Vegetable oil & 9.0 \\
\hline Condiment mixture & 4.0 \\
\hline Refined wheat flour & 3.0 \\
\hline Spice mixture & 2.0 \\
\hline Table salt & 1.75 \\
\hline Monosodium Glutamate & 0.5 \\
\hline Sodium Tripolyphosphate & 0.3 \\
\hline Egg & 3.0 \\
\hline Sodium nitrite & $120 \mathrm{ppm}$ \\
\hline
\end{tabular}

Table.4 Effect of capsicum on $\mathrm{pH}$, cooking yield and proximate composition of cooked chicken sausages. (Mean \pm SE)

\begin{tabular}{|l|c|c|c|c|}
\hline \multirow{2}{*}{ Parameter } & \multicolumn{4}{|c|}{ Levels of capsicum (\%) } \\
\cline { 2 - 5 } & $\mathbf{0}$ & $\mathbf{7}$ & $\mathbf{1 4}$ & $\mathbf{2 1}$ \\
\hline $\mathrm{pH}$ & $6.15 \pm 0.54$ & $6.05 \pm 0.42$ & $6.05 \pm 0.22$ & $6.03 \pm 0.23$ \\
\hline Cooking Yield (\%) & $91.51^{\mathrm{d}} \pm 0.53$ & $89.83^{\mathbf{c}} \pm 0.40$ & $89.01^{\mathbf{b}} \pm 0.91$ & $87.83^{\mathbf{a}} \pm 0.40$ \\
\hline Moisture (\%) & $61.15^{\mathbf{a}} \pm 0.36$ & $63.29^{\mathbf{b}} \pm 0.63$ & $64.18^{\mathbf{c}} \pm 0.40$ & $65.01^{\mathbf{d}} \pm 0.63$ \\
\hline Crude Protein (\%) & $16.88^{\mathbf{d}} \pm 0.13$ & $15.75^{\mathbf{c}} \pm 0.82$ & $14.86^{\mathbf{b}} \pm 0.03$ & $13.58^{\mathbf{a}} \pm 0.50$ \\
\hline Ether extract (\%) & $13.49^{\mathbf{c}} \pm 0.39$ & $12.67^{\mathbf{b c}} \pm 0.73$ & $12.07^{\mathbf{b}} \pm 0.83$ & $11.21^{\mathbf{a}} \pm 0.81$ \\
\hline Ash (\%) & $2.78^{\mathbf{b}} \pm 0.31$ & $2.35^{\mathbf{b}} \pm 0.40$ & $1.83^{\mathbf{a}} \pm 0.40$ & $1.61^{\mathbf{a}} \pm 0.42$ \\
\hline $\begin{array}{l}\text { Emulsion Stability } \\
\%(\text { Raw) }\end{array}$ & $91.51^{\mathbf{c}} \pm 0.76$ & $89.68^{\mathbf{b}} \pm 0.96$ & $88.61^{\mathbf{a b}} \pm 0.95$ & $87.45^{\mathbf{a}} \pm 0.50$ \\
\hline Crude Fibre (\%) & $0.58^{\mathbf{a}} \pm 0.03$ & $0.81^{\mathbf{a}} \pm 0.06$ & $1.19^{\mathbf{b}} \pm 0.04$ & $1.45^{\mathbf{b}} \pm 0.03$ \\
\hline
\end{tabular}

"Mean \pm SE with different superscripts in a row differs significantly $(\mathrm{P}<0.05) . \mathrm{n}=6$ 
Table.5 Effect of capsicum on sensory attributes of cooked chicken sausages (Mean \pm SE)

\begin{tabular}{|l|c|c|c|c|}
\hline \multirow{2}{*}{ Sensory attribute } & \multicolumn{4}{|c|}{ Levels of capsicum (\%) } \\
\cline { 2 - 5 } & 0 & $\mathbf{7}$ & $\mathbf{1 4}$ & $\mathbf{2 1}$ \\
\hline $\begin{array}{l}\text { Appearance and } \\
\text { colour }\end{array}$ & $6.90^{\mathrm{ab}} \pm 0.11$ & $7.23^{\mathrm{b}} \pm 0.11$ & $6.90^{\mathrm{ab}} \pm 0.15$ & $6.76^{\mathrm{a}} \pm 0.15$ \\
\hline Flavour & $6.80^{\mathrm{ab}} \pm 0.16$ & $7.19^{\mathrm{b}} \pm 0.16$ & $6.90^{\mathrm{ab}} \pm 0.16$ & $6.52^{\mathrm{a}} \pm 0.16$ \\
\hline Juiciness & $5.14^{\mathrm{a}} \pm 0.18$ & $6.30^{\mathrm{b}} \pm 0.16$ & $6.00^{\mathrm{b}} \pm 0.19$ & $6.71^{\mathrm{c}} \pm 0.17$ \\
\hline Texture & $6.90^{\mathrm{b}} \pm 0.22$ & $6.90^{\mathrm{b}} \pm 0.16$ & $6.38^{\mathrm{b}} \pm 0.21$ & $5.71^{\mathrm{a}} \pm 0.14$ \\
\hline Overall acceptability & $6.80^{\mathrm{b}} \pm 0.11$ & $7.28^{\mathrm{b}} \pm 0.26$ & $6.00^{\mathrm{a}} \pm 0.11$ & $5.57^{\mathrm{a}} \pm 0.13$ \\
\hline
\end{tabular}

*Mean \pm SE with different superscripts in a row differs significantly $(\mathrm{p}<0.05)$. Mean values are scores on 8 point descriptive scale where 1- extremely poor and 8- extremely desirable.

Control sausages

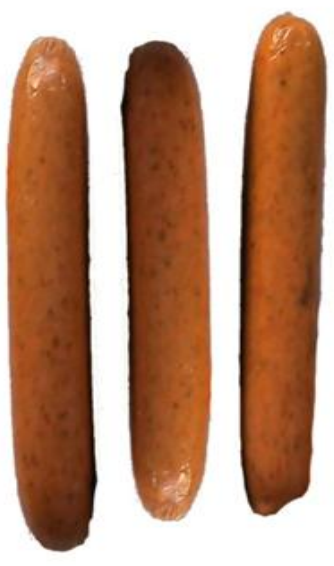

Sensory attributes of cooked chicken sausages: Table 5 revealed a significant $(\mathrm{p}<0.05)$ influence on appearance and colour, flavour, juiciness, texture and overall acceptability of sausages as a result of incorporation with capsicum. The appearance and colour of sausages decreased gradually with the increasing level of capsicum incorporation. Appearance decreased as the level of capsicum incorporation increased, however the decrease was highest at $21 \%$ level although comparable with other levels
Sausages with optimum levels of Capsicum (7\%)
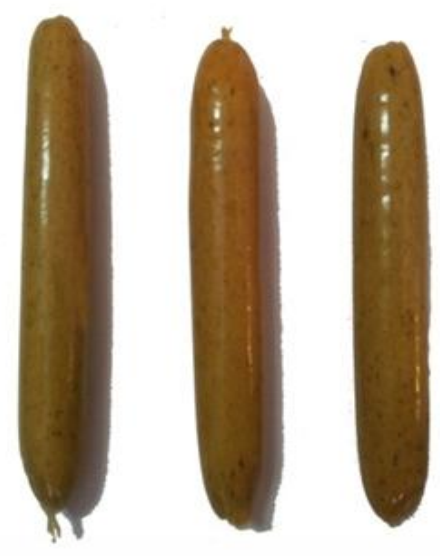

of incorporation. Fernandez-Lopez, 2002 reported that the addition of paprika to minced meat reduced lightness and the modifications of the colour of products containing paprika were principally due to changes which the spice underwent. The flavour, and overall acceptability scores were significantly $(\mathrm{p}<0.05)$ lower at 21 percent level as compared to control however the scores were highest at 7 percent level of incorporation which is comparable to control. Juiciness scores were significantly $(\mathrm{p}<0.05)$ 
higher at $21 \%$ level as compared to control and other two levels of capsicum incorporation, although the scores were comparable at 7 and $14 \%$ level of incorporation. The sausages were extremely juicy at $21 \%$ level of capsicum incorporation. Increase in juiciness might be due to increase in moisture content in the treated products. The texture score followed a linear decreasing trend in the present study. The products with $21 \%$ added capsicum in the formulation had significantly $(\mathrm{p}<0.05)$ lower texture score as compared to control. As fibre content increased texture of sausages decreased. Decrease in texture score might be attributed to increase in the fibre content of the product with increase in the level of capsicum which is having high moisture retention capacity. The overall acceptability score of the products was highest at 7\% level of capsicum incorporation. The overall acceptability score was least at $21 \%$ level of incorporation and was comparable with 14 level of incorporation. The highest score for overall acceptability in the sausage incorporated with $7 \%$ capsicum might be due to higher appearance and colour and texture score in the product. This study is in conjunction with Dasiewicz and Urcus (2009) who reported that fibre incorporation did not negatively influence the sensory properties of products.

The sausages with $7 \%$ level of capsicum incorporation had highest $(\mathrm{P}<0.05)$ overall acceptability and other sensory scores. Hence $7 \%$ incorporation level of capsicum was found optimum for preparation of chicken sausages.

\section{Acknowledgement}

The authors are thankful to the Hon'ble Dean, Arawali Veterinary College, Sikar for providing the necessary facilities to carry out the original work.
Competing interest: Authors have no competing interest regarding publication of manuscript.

\section{References}

Aleson-Carbonell, L., Fernandez-Lopez, J., Sendra, E. and Sayas-Barbera, E. 2004. Quality characteristics of a nonfermented sausage formulated with lemon albedo. J. Sci. Food and Agri., 84: 2077-2084.

Anderson, E.T. and Berry, B.W. 2001. Effects of inner pea fibre on fat retention and cooking yield in high fat ground beef. Food Res. Int., 34: 689-694.

Anonymous. 2011. In: Capsicum Nutrition and Health Benefits of Capsicum. Access on www.diethealthclub.com. June 23, 2011.

AOAC. 1995. Official methods of analysis. $16^{\text {th }}$ ed., Association of official Agricultural Chemists, Washington, DC.

Bhosale, S.S., Biswas, A.K., Sahoo, J., Chatli, M.K., Sharma, D.K. and Sikka, S.S. 2011. Quality evaluation of functional chicken nuggets incorporated with ground carrot and mashed sweet potato. Food Sci. Technol. Int., 17(3): 233-239.

Candogan, K. 2002. The effect of tomato paste on some quality characteristics of beef patties during refrigerated storage. European Food Res. Technol., 215: 305-309.

Chang, C.C., Yang, J.H., Chou, C.K. and Tseng, T. 2010. Effect of replacing pork lard with carrot and onion on the quality of Chinese style sausage. $J$. Agri. Assoc. Taiwan, 11(4): 374-386.

Dasiewicz, K. and Urcus, P. 2009. Influence of addition of fibre preparations on quality of added water meat block products. Roczniki Instytutu Przemystu Miesnego i Tluszczowego, 47(2): 8694. 
Fernandez-Gine, J.M., Fernandez-Lopez, J., Sayas-Barbera, E., Sendra, E. and Perez Alvarez, J.A. 2004. Lemon albedo as a new source of dietary fiber: application to bologna sausages. Meat Sci., 67: 7-13.

Fernandez- Lopez, J., Perez-Alvarez, J.A., Sayas-Barbera, E., Lopez-Santovena, F. 2002. Effect of paprika (Capsicum annum) on color of Spanish-type sausages during the resting stage. $J$. Food Sci., 67(6): 2410-2414.

Grigelmo-Miguel, N., Abadias-Seras, M.I. and Martin-Bellosos, O. 1999. Characterization of low-fat highdietary fibre frankfurters. Meat Sci., 52: 247-256.

Hashim, I.B. and Khalil, A.H. 1999. Quality characteristics of beef patties extended with date fibre. $66^{\text {th }}$ Annual meeting, Institute of food technologists, Orlando, FL. June 2006.

Kassem, M.A., Emara, M.M.T. 2010. Quality and acceptability of value added beef burger. World J. Dairy \& Food Sci., 5(1): 14-20.

Keller, J.E., Skelley, G.C. and Acton, J.C. 1974. Effect of meat particle size and casing diameter on summer sausage properties during. J. Milk Food. Technol., 37: 297-300.

Mc Donald, T. 2009. In: Prospects for India's Poultry Sector. United States Department of Agriculture, Economic Research Service. Publishing and
Communications Branch, Economic Research Service, USDA.

Semen, D.L., Moody, W.G., Fox, J.D. and Gay, N. 1987. Influence of hot and cold deboning on the palatability, textural and economic traits of restructured beef steaks. J. Food Sci., 52: 879-882, 889 .

Snedecor, G.W. and Cochran, W.G. 1980. In: Statistical Methods. $7^{\text {th }}$ ed., Oxford and IBH Publishing Co, Calcutta.

Townsend, W.E., Witnauer, L.P., Riloff, J.A. and Swift, C.E. 1968. Comminuted meat emulsions. Differential thermal analysis of fat transition. Food Technol., 22: 319-323.

Valeria, S., Eim, S.S., Carmon, R. and Anton LF. 2008. Effect of addition of carrot dietary fibres on the ripening process of dry fermented sausages (sobrassada. Meat Sci., 80: 173-182.

Verma, A.K., Anjaneyulu, A.S.R., Thomas, R. and Kondaiah, N. 2009. Effect of different fats on the quality of goat meat patties incorporated with full-fat soy paste. J. Muscle Foods, 20(1): 3753

Verma, A.K., Sharma, B.D. and Banerjee, R. 2010. Effect of sodium chloride replacement and apple pulp inclusion on the physico-chemical, textural and sensory properties of low fat chicken nuggets. Food Sci. Technol., 43(4): 715-719.

\section{How to cite this article:}

Parveez Ahmad Para, Praveen Kumar Praveen and Subha Ganguly. 2017. Effect of Capsicum on the Physico-Chemical Properties and Sensory Attributes of Chicken Sausages. Int.J.Curr.Microbiol.App.Sci. 6(2): 1043-1052. doi: http://dx.doi.org/10.20546/ijcmas.2017.602.140 